\title{
LIPID PEROXIDATION AND PROTEIN OXIDATION INDUCED BY DIFFERENT NANOPARTICLES IN ZEBRAFISH ORGANS
}

\author{
CARrillo, Y. - Torres-Duarte, C. - Oviedo, M. J. - Hirata, G. A. - \\ HUERTA-SAQUERO, A. - VAZQUEZ-DUHALt, R. \\ Centro de Nanociencias y Nanotecnología UNAM, \\ Ensenada, Baja California, Mexico 22800. \\ *Corresponding author \\ e-mail: rvd@cnyn.unam.mx \\ (Received $2^{\text {nd }}$ Nov 2014; accepted $1^{\text {st }}$ Dec 2014)
}

\begin{abstract}
The protein oxidation and the lipid peroxidation induced by the presence of five different kinds of nanoparticles were determined in different tissues of zebrafish (Danio rerio). Both oxidative stress markers showed to be dose-dependent. At $1 \mathrm{ppm}$ nanoparticle concentration, the five assayed nanoparticles showed higher protein oxidation than the control experiments. Europium-doped yttrium oxide $\left(\mathrm{Y}_{2} \mathrm{O}_{3}: \mathrm{Eu}\right)$ and carboxylated multi-walled carbon nanotubes (MWCNT-COOH) showed the highest effect, especially in ovaries, testicles and brain, reaching carbonyl content in proteins up to 4-times higher than control, while bismuth germanate (BGO) and MWCNT-COOH nanoparticles induced lipid peroxidation in all analyzed tissues, reaching values up to two-times higher than those from non-exposed control fish. BGO and silver nanoparticles (AgNP) showed less oxidative effect; nevertheless, the protein oxidation still accounted for up to 3-times the control fish values. At $1 \mathrm{ppm}$, the protein oxidation induced by some nanoparticles reached the values obtained in the experiments with $100 \mu \mathrm{M} \mathrm{H}_{2} \mathrm{O}_{2}$. On the other hand, no significant differences were found in gene expression of oxidative stress markers after $48 \mathrm{~h}$ treatment. The results from this work clearly indicate that exposure to those nanoparticles may cause significant protein and lipid oxidative damage.
\end{abstract}

Keywords: lipid peroxidation, protein oxidation, nanoparticles, oxidative stress, zebrafish, toxicity

\section{Introduction}

Nanotechnology is the origin of a new revolution in material technology with numerous potential applications. The use of nano-structured materials has more than quadrupled in the last 5 years. It is estimated that there are more than 1,000 nanostructured commercial products (Papp et al., 2008; McIntrye, 2012). Nanoparticles (NPs) can be made from almost any kind of materials, and the most used so far are made from carbon, silicon, titanium or other similar elements and materials. Many NPs are also made from metals or metal oxides, containing elements such as cadmium, cerium, copper, germanium, gold, iron, lead, selenium, silver, zinc, or zirconium. In general, the main NPs classes with commercial applications are fullerenes and singlewall/multi-wall carbon nanotubes, quantum dots, metal oxide-based NPs, and polymers (Powell and Kanarek, 2006).

Among the numerous commercial applications of NPs there are antimicrobial preparations, medical materials and devices, medical diagnostics, cosmetics, food packaging, anti-odor textiles, electronics, self-cleaning surfaces, UV-resistant coatings and paints, and lubricants. As the use of NPs increases, it is expected that their presence in aquatic environment will increase. In addition, NPs in aquatic systems can be formed by natural abiotic or biotic processes, induced by human activity (e.g. mining), incidentally introduced to aquatic systems, or intentionally added to these systems 
(Delay and Frimmel, 2012; Wigginton et al., 2007). Specifically, NPs have been proposed as potentially useful for water treatment processes (Wiesner, 2006; Wiesner and Bottero, 2007). The physicochemical behavior of NPs in aquatic environments has been reviewed (Lead and Wilkinson, 2006; Nowack and Bucheli, 2007; Christian et al., 2008; Baalousha et al., 2009). These molecular interactions are essential for the understanding of the mobility and transport, bioavailability, ecotoxicity, and reactivity of NPs in the aqueous phase. It has been found that when nanoparticles are dosed to water columns, they tend to precipitate to the subaquatic sediment, but this doesn't reduce its bioavailability since they accumulated in plant and animal biomass (Lowry et al., 2012).

The ecological importance of the NPs presence in aquatic systems has been discussed (Delay and Frimmel, 2012; Baun et al., 2008) and it is clear that the behavior and role of NPs in aquatic systems is very complex. In addition, the information of NPs effects and toxicity mechanisms in aquatic systems and organisms is still scarce, and the specific toxicity of NPs and their long-term impact on environment and human health remains basically unknown (Papp et al., 2008). These are important issues that need to be assessed in order to understand and even forecast the real risk that nanomaterials may pose to the environment and human health (Wiesner and Botero, 2012).

The current state of knowledge regarding the biological and health effects of NPs has been recently reviewed (Papp et al., 2008; Stark, 2011; Sharifi et al., 2012; Pattan and Kaul, 2012). Several different mechanisms for NPs toxicity have been reported. The increased production of reactive oxygen species (ROS) seems to be an important toxicity mechanism in cells induced by NPs (Nel et al., 2006; Unfried et al., 2007; Moller et al., 2010). These ROS include, among others, hydroxyl radicals, lipidoxyl or peroxyl radicals, singlet oxygen, and peroxinitrite formed from nitrogen oxide (NO). The modulation of several cellular events, including signal transduction, proliferative response, gene expression and protein redox regulation requires moderate amounts of ROS. However, high ROS levels induce oxidative stress which can damage cells by peroxidizing lipids, oxidizing proteins, disrupting DNA, interfering with signaling functions, modulating gene transcription, and finally, inducing cancer, renal disease, neurodegeneration, cardiovascular or pulmonary diseases.

In particular, lipid peroxidation is considered highly dangerous as it alters cell membrane properties (Lam et al., 2006). The chemical composition of nanoparticles seems to be the most decisive factor determining the formation of ROS in exposed cells (Limbach et al., 2007). For example, fullerene and its water-soluble derivative caused membrane disruption in rat liver microsomes by inducing significant oxidative damage (Kamat et al., 2000). Fullerenes are lipophilic and insert into lipid-rich regions (liver and gills) in fish. Other nanomaterials have been shown to selectively translocate into the brain via the olfactory bulb in mammals and fish (Oberdörster, 2004). The toxic effect of ROS could be more pronounced in the central nervous system due to the high content of unsaturated fatty acids in the cells, which are more susceptible to peroxidation (Adibhatla and Hatcher, 2010).

On the other hand, the oxidation of proteins in vertebrates has been the subject of several studies (Stadtman, 1991). Among the various oxidative modifications of amino acids in proteins, carbonyl formation may be an early marker for protein oxidation (Stadtman, 2004). $\mathrm{TiO}_{2}$ NPs showed a dose-dependent linear increase in generating ROS and the generated ROS correlated with the protein oxidation in both in vivo and in vitro experiments (Han et al., 2012). The loss of membrane bound enzymes was also 
detected. Finally, $\mathrm{TiO}_{2}$ NPs intranasally supplied to mice (Wang et al., 2008) induced a significant oxidative damage in brain tissue. The whole brain was affected, and lipid peroxidation, protein oxidation, increased activities of catalase, and an excessive release of glutamic acid and nitric oxide were detected.

There is a consensus that NPs in environmental systems are of ecotoxicological and public health relevance (Oberdörster, 2004; Ray et al., 2009; Stone et al., 2009). Thus, there is an urgent need for the evaluation of NPs biological effects due to the rapid development and commercialization of nano-structured products. In this work, different kinds of NPs are evaluated for oxidative stress in zebrafish. Different tissue targets are studied and the risk of the NPs presence for aquatic organisms is discussed.

\section{Materials and methods}

\section{Nanoparticles}

Europium-doped hydroxyapatite powder and bismuth germanate $\left(\mathrm{Bi}_{4} \mathrm{Ge}_{3} \mathrm{O}_{12}, \mathrm{BGO}\right)$ and $\mathrm{Y}_{2} \mathrm{O}_{3}: \mathrm{Eu}^{3+}$ (with silica shell) nanoparticles were synthesized by sol-gel method and subsequent annealing (Taxak et al., 2009; Oviedo et al., 2012). The carboxylated multiwalled carbon nanotubes (MWCNT-COOH) were prepared by chemical vapor deposition and purified by refluxing in an aqueous $\mathrm{HNO}_{3}$ solution $(2.6 \mathrm{M})$ for $6 \mathrm{~h}$, washed several times with distillated water and dried for $12 \mathrm{~h}$ at $80^{\circ} \mathrm{C}$ (Lin et al., 2002). Silver nanoparticles (AgNP) from Sovereign Silver ${ }^{\mathrm{TM}}$ (Russia) were a kind gift of Dr. Nina Bogdanchikova (CNyN-UNAM). The physical properties of the different nanoparticles are shown in Table 1.

Table 1. Physical properties of the different nanoparticles.

\begin{tabular}{|l|c|c|c|c|c|}
\hline Property & HA:Eu & BGO & MWCNT & AgNP & Y2O3:Eu \\
\hline Size diameter & $50-100 \mathrm{~nm}$ & $10-15 \mathrm{~nm}$ & $80-100 \mathrm{~nm}$ & $10-30 \mathrm{~nm}$ & $50-100 \mathrm{~nm}$ \\
\hline Zeta potential & $-10 \mathrm{mV}$ & $\mathrm{ND}$ & $-27.3 \mathrm{mV}$ & -21.2 & $-25.0 \mathrm{mV}$ \\
\hline Excitation maximum & 280 and $394 \mathrm{~nm}$ & $284 \mathrm{~nm}$ & --- & $215 \mathrm{~nm}$ & $237 \mathrm{~nm}$ \\
\hline Emission maximum & 575,613 and $620 \mathrm{~nm}$ & $485 \mathrm{~nm}$ & --- & $300 \mathrm{~nm}$ & $611 \mathrm{~nm}$ \\
\hline Melting point & $1200{ }^{\circ} \mathrm{C}$ & $1050{ }^{\circ} \mathrm{C}$ & --- & $810^{\circ} \mathrm{C}$ & $1600^{\circ} \mathrm{C}$ \\
\hline
\end{tabular}

ND. Not determined

\section{Fish experiments}

Adult and healthy zebrafish (Danio rerio) of $0.470 \pm 0.166 \mathrm{~g}$ were obtained from a local fish farm (Granja Acuario Antártico, Cuernavaca, Mexico). Fish were acclimatized in glass tanks at room temperature $\left(25 \pm 2^{\circ} \mathrm{C}\right)$ for 2 days with a photoperiod of $12 \mathrm{~h}$ light/12 $\mathrm{h}$ dark and they were fed twice a day with a commercial diet. Experiments were carried out in a $20 \mathrm{~L}$ aquarium containing $16 \mathrm{~L}$ of chlorinefree treated water. Ten fish were treated with 0.5 or $1 \mathrm{ppm}$ of NPs and ten fish were used as control without NPs. Every set of treatments and controls were carried out in three independent experiments. After $48 \mathrm{~h}$ of treatment, fish were anesthetized on ice, and then dissected to obtain liver, ovaries, testicles, gills and brain tissues. Positive control experiments for oxidative stress were performed treating fish in the presence 
of $100 \mu \mathrm{M}$ hydrogen peroxide for $48 \mathrm{~h}$. All tissues were kept in liquid nitrogen and analyzed immediately.

\section{Protein oxidation}

The extent of protein oxidation in the different tissues was determined as the carbonyl content in the protein fraction (Levine et al., 1991). Tissues (150-200 mg) from fish treatments with 0.5 or 1 ppm of NPs, or with $100 \mu \mathrm{M} \mathrm{H}_{2} \mathrm{O}_{2}$ (positive control) were placed in an eppendorf tube and 4 volumes of $50 \mathrm{mM}$ HEPES buffer ( $\mathrm{pH}$ 7.2) containing $0.1 \mathrm{mM}$ phenylmethylsulfonyl fluoride were added, and then grinded with pellet pestle (Kimble-Chase 749521-1590). The homogenized mixture was centrifuged at $10,000 \mathrm{~g}$ for $5 \mathrm{~min}$ at $4^{\circ} \mathrm{C}$. Subsequently, $10 \mu \mathrm{L}$ of streptomycin $(20 \%)$ were added to $100 \mu \mathrm{L}$ of supernatant in order to remove the nucleic acids that may erroneously contribute to higher estimation of carbonyls. The mixture was kept at $25^{\circ} \mathrm{C}$ for $15 \mathrm{~min}$ and the precipitated nucleic acids were removed by centrifugation at $10,000 \mathrm{~g}$ for $5 \mathrm{~min}$ at $4^{\circ} \mathrm{C}$. To a $100 \mu \mathrm{L}$ aliquot of supernatant, $400 \mu \mathrm{l}$ of $10 \mathrm{mM} 2,4-$ dinitrophenylhydrazine were added to and kept for 1 hour under gentle shaking. Then, the protein was precipitated by adding $500 \mu \mathrm{L}$ of trichloroacetic acid $20 \%$ and recovered by centrifugation at $10,000 \mathrm{~g}$ for $5 \mathrm{~min}$ at $4^{\circ} \mathrm{C}$. The pellet was washed three times with a ethanol:ethylacetate $(50: 50 \mathrm{v} / \mathrm{v})$ solution. The pellet was dissolved in 500 $\mu \mathrm{L}$ of $6 \mathrm{M}$ guanadine containing $10 \mathrm{mM}$ dithiothreitol at $37^{\circ} \mathrm{C}$. An aliquot of $400 \mu \mathrm{L}$ of this protein solution were diluted with $600 \mu \mathrm{L}$ of water and spectrometrically read at $370 \mathrm{~nm}$ (Oberdörster, 2004).

\section{Lipid peroxidation}

The different tissues from fish treatments with 0.5 or $1 \mathrm{ppm}$ of NPs, or with $100 \mu \mathrm{M}$ $\mathrm{H}_{2} \mathrm{O}_{2}$ (positive control) were analyzed for lipid peroxidation. The amount of lipid peroxides was estimated by using the Xylenol Orange reagent (Nourooz Zadeh et al., 1994). The FOX reagent contains $2.5 \mathrm{mM}$ ammonium ferrous sulphate and $110 \mathrm{mM}$ perchloric acid in a methanol:water $(90: 10 \mathrm{v} / \mathrm{v})$ solution. FOX reagent $(900 \mu \mathrm{L})$ was added to $100 \mu \mathrm{L}$ of homogenized tissue supernatant (see previous section) and kept for $30 \mathrm{~min}$ at $25^{\circ} \mathrm{C}$. Then the reaction mixture was read at $560 \mathrm{~nm}$ (Gay and Gebicki, 2003). The molar concentration of lipid peroxides was then estimated comparing the absorbance values with those obtained from a standard curve with different concentrations of hydrogen peroxide.

\section{Protein determination}

The amount of protein in the tissue homogenates was spectrophotometrically determined with the BioRad protein reagent using BSA as standard.

\section{Isolation of RNA and reverse transcription}

Six fish were reared in $6 \mathrm{~L}$ containing $1 \mathrm{ppm}$ of the corresponding nanoparticle (BGO, $\mathrm{Y}_{2} \mathrm{O}_{3}-\mathrm{Eu}^{3+}, \mathrm{MWCNT}-\mathrm{COOH}$ and $\mathrm{AgNP}$ ) in glass flasks at room temperature (25 $\pm 2^{\circ} \mathrm{C}$ ). Three independent replicates in separated glass flasks were used for each treatment. After $48 \mathrm{~h}$ of exposure, fish were anesthetized on ice and frozen in liquid nitrogen. Liver and brain were dissected out and stored at $4^{\circ} \mathrm{C}$ in RNA later (Qiagen, USA). After $24 \mathrm{~h}$, RNA later was removed and the tissues were stored at $-20^{\circ} \mathrm{C}$. The 
rest of the body was frozen and stored at $-80^{\circ} \mathrm{C}$. The different tissues were grounded in a mortar with liquid nitrogen. The tissue was then recovered in $250 \mu \mathrm{L}$ TRI Reagent (Sigma, USA), and total RNA was isolated according to the manufacturer's instructions. The absorbance ratio $260 / 280 \mathrm{~nm}$ was measured in a Nanodrop. The banding patterns on a $1 \%$ agarose gel were used to verify the quality of the RNA in each sample. One $\mu \mathrm{g}$ of total RNA was treated with DNase I, RNase-free (Fermentas, USA) according to manufacturer's instructions. Reverse transcription of mRNA was carried out with the SuperScript III First-Strand Synthesis System for RT-PCR (Invitrogen, USA). Finally, samples were diluted 4-fold and $1 \mu \mathrm{L}$ was used for the real-time quantitative polymerase chain reaction.

\section{Gene expression analysis}

Real-time quantitative PCR was performed using a StepOne Real Time PCR system (Applied Biosystems, USA). The qPCR reactions were carried out in $10 \mu \mathrm{L}$ of Maxima SYBR Green /ROX qPCR Master Mix (2X) (Fermentas, USA). The following PCR protocol was used: Denaturation for $10 \mathrm{~min}$ at $95^{\circ} \mathrm{C}$, followed by 40 cycles of $15 \mathrm{~s}$ at $95^{\circ} \mathrm{C}$, and $1 \mathrm{~min}$ at $60^{\circ} \mathrm{C}$. The correct primer amplification was confirmed by agarose gel electrophoresis. Oligonucleotide primer pairs of oxidative stress genetic expression markers; superoxide dismutase (Sod1), the transcription factor Forkhead box protein O1 (FoxO1) (Subauste and Burant, 2007), and the glutamate-l-cysteine ligase catalytic subunit (Gclc) (Mougiakakos et al., 2012) are described in Table 2. $\beta$-actin (bact), tubulin alpha I (Tub) and TATA-box binding protein (Tbp) transcripts were used to standardize the results by eliminating variations in mRNA and cDNA quantity. Each experiment was carried out in triplicate.

Table 2. Oxidative stress genetic expression markers. Oligonucleotide primer pairs of superoxide dismutase (Sod1), the transcription factor Forkhead box protein O1 (FoxOl), and the glutamate-l-cysteine ligase catalytic subunit (Gclc). $\beta$-actin (bact), tubulin alpha I (Tub) and TATA-box binding protein (Tbp) transcripts were used to standardize the results by eliminating variations in $m R N A$ and cDNA quantity.

\begin{tabular}{|l|l|l|l|c|}
\hline mRNA & Accesion number & Forward (5'-3') & Reverse (5'-3') & Position \\
\hline Gcle & NM_199277.2 & ACAGCTATCTGGAGAACATGGAGG & TGTTTGGCAACAAACTCCCTCATC & 1628-1763 \\
\hline FoxOla & NM_001077257.2 & GACCTCATGCCTTCAGTGGACACT & TGTGTGGGTGAGAAAGAGTGTGAC & $1393-1535$ \\
\hline Sodl & NM_131294.1 & TGAGACACGTCGGAGACCTGGGTA & CCACCCTTCCCCAAGTCATCCTCC & $304-460$ \\
\hline bact & AF057040 & ATGGATGAGGAAATCGCTGCC & CTCCCTGATGTCTGGGTCGTC & $54-180$ \\
\hline Tbp & NM_200096 & CGGTGGATCCTGCGAATTAT & GGTTATGAAGCAAAACAACA & $51-146$ \\
\hline Tub & AF029250 & TCTTTGTAGACCTGGAGCCC & TCAATGAGTTCCTTGCCAAT & $197-347$ \\
\hline
\end{tabular}

\section{Gene expression statistical analysis}

Results of gene expression were normalized using the geometric mean of the three control genes using the Biogazelle qbasePlus software (Gent, Belgium). The relative expression values for each gene were calculated taking as reference the value obtained for the control treatment. 


\section{Statistical analysis}

Data were analyzed by a one-way analysis of variance (ANOVA). If the results of the ANOVA indicated significant differences among the mean values, then multiple comparisons of mean values were performed using Tukey's test. Differences were reported as statistically significant at $\mathrm{P}<0.05$. All the statistical analyses were performed using the statistical program SIGMA STAT, 3.1 (Arlington, VA, USA).

\section{Results}

Oxidative stress implies a cellular state whereby reactive oxygen species (ROS) production exceeds its metabolism overpassing cellular defenses. The oxidant effect of nanoparticles was estimated in zebrafish (Danio rerio) after $48 \mathrm{~h}$ exposure to two different NPs concentrations, $0.5 \mathrm{ppm}$ and $1.0 \mathrm{ppm}$. Five different kinds of nanoparticles were studied including europium-doped hydroxyapatite (HA:Eu), bismuth germanate (BGO), europium-doped yttrium oxide $\left(\mathrm{Y}_{2} \mathrm{O}_{3}: \mathrm{Eu}\right)$, silver nanoparticles (AgNP), and carboxylated multi-walled carbon nanotubes (MWCNT$\mathrm{COOH})$. In addition, a positive control was performed in which fish were treated with $100 \mu \mathrm{M}$ of hydrogen peroxide. The $\mathrm{H}_{2} \mathrm{O}_{2}$ concentration of this positive control was chosen after preliminary experiments with 10,50 and $100 \mu \mathrm{M}$ of $\mathrm{H}_{2} \mathrm{O}_{2}$, the latter being the one that showed important protein oxidation and lipid peroxidation in the different tissues.

The formation of carbonyl groups is an early marker for protein oxidation (Stadtman, 2004) and was determined in five different tissues of zebrafish after exposure to different NPs. Carbonyl content in liver, ovaries, testicles, gills and brain values were compared with those of a positive control for oxidative stress induced by the presence of $100 \mu \mathrm{M}$ of hydrogen peroxide (Fig. 1). At $0.5 \mathrm{ppm}$ concentration, $\mathrm{Y}_{2} \mathrm{O}_{3}: \mathrm{Eu}$ and $\mathrm{MWCNT}-\mathrm{COOH}$ induced, by far, the highest oxidative stress followed by AgNP, while no protein oxidation was found with HA:Eu and BGO NPs when compared to control experiments (Fig. 1). Nevertheless, this increase in carbonyl content in proteins is lower than those found in the positive control with $100 \mu \mathrm{M} \mathrm{H}_{2} \mathrm{O}_{2}$, in which liver, ovaries, testicles and brain are especially prone to protein oxidation. At low NPs concentration all tissues seemed to be equally sensible.

On the other hand, in all cases, when NPs concentration was increased from 0.5 ppm to $1 \mathrm{ppm}$, an increase was observed on protein oxidation. At high NPs concentration (1 ppm), the five assayed NPs showed higher concentration of carbonyl groups than the control experiments (Fig. 1). Here, again the $\mathrm{Y}_{2} \mathrm{O}_{3}: \mathrm{Eu}$ and MWCNT-COOH nanoparticles showed the higher effect, specially in ovaries, testicles and brain. The carbonyl group content in these tissues reached up to 4-times higher than in control fish after $48 \mathrm{~h}$ treatment. AgNP showed lower but significant oxidative effect, nevertheless, the protein oxidation still accounted for up to 3 -times the control fish values. At $1 \mathrm{ppm}$, the induced protein oxidation by NPs reached the values obtained in the experiments with $100 \mu \mathrm{M} \mathrm{H}_{2} \mathrm{O}_{2}$. These results clearly indicate that exposure to $1 \mathrm{ppm}$ concentration of these NPs for $48 \mathrm{~h}$ is able to induce an important oxidative stress on fish demonstrated by the carbonyl content in protein in the different fish tissues. 

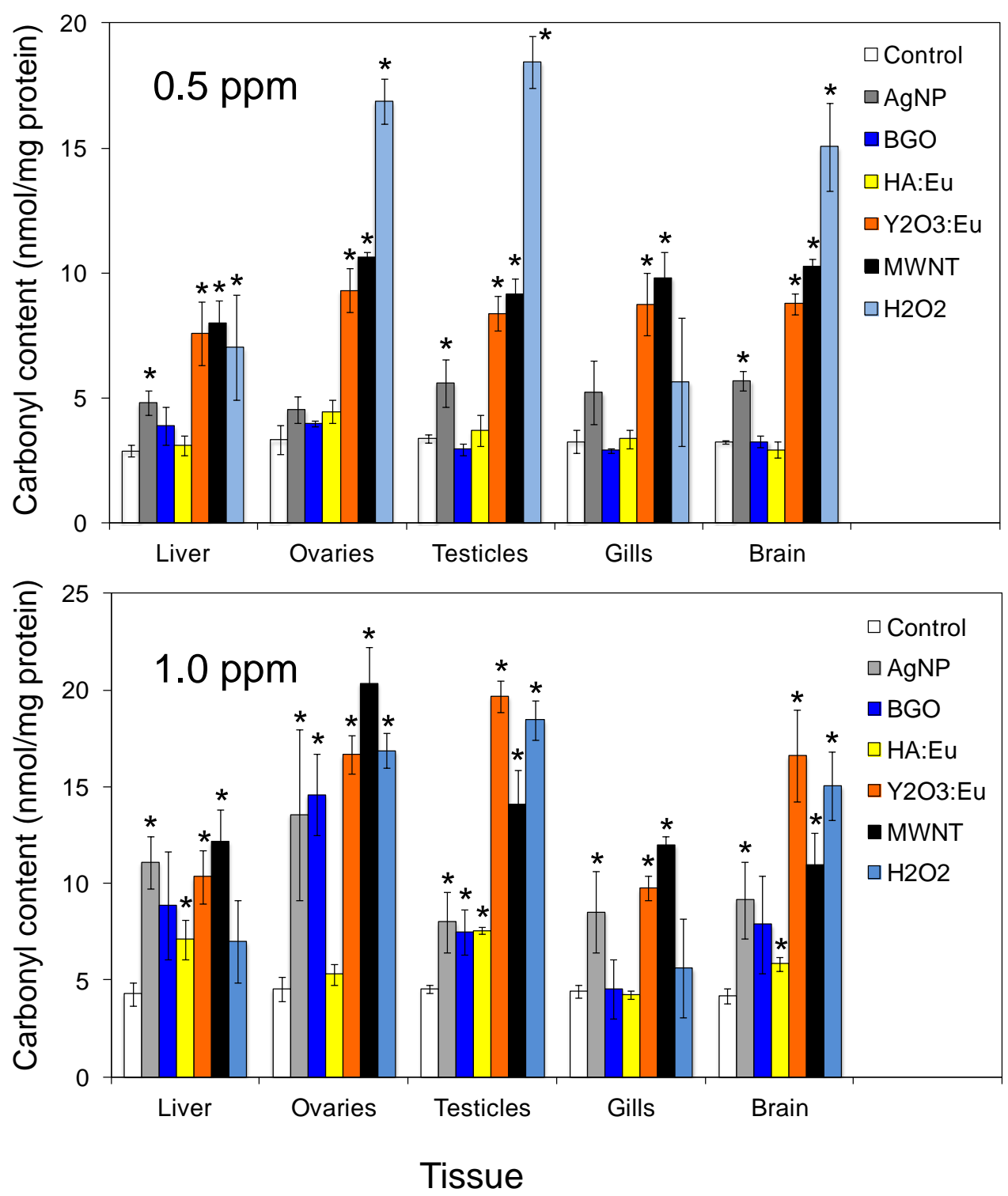

Figure 1. Protein oxidation of different zebrafish tissues estimated as carbonyl content in proteins. a) Fish exposed to 0.5 ppm of nanoparticles for $48 \mathrm{hrs}$. b) Fish exposed to 1 ppm of nanoparticles for 48 hrs. (*)Values significantly different at $P<0.05$ with respect to the control.

The concentration of lipid peroxides in the different tissues was estimated after 48 h fish exposure to NPs (Fig. 2). At $0.5 \mathrm{ppm}$ of NPs there is low effect, except with MWCNT-COOH nanoparticles in ovaries, testicles and brain. Lipid peroxidation also showed to be dose-dependent. At high NPs concentration (1 ppm) MWCNT-COOH nanoparticles induced higher lipid peroxides content in all analyzed tissues, reaching values up to two-times higher than those from non-exposed control fish. 

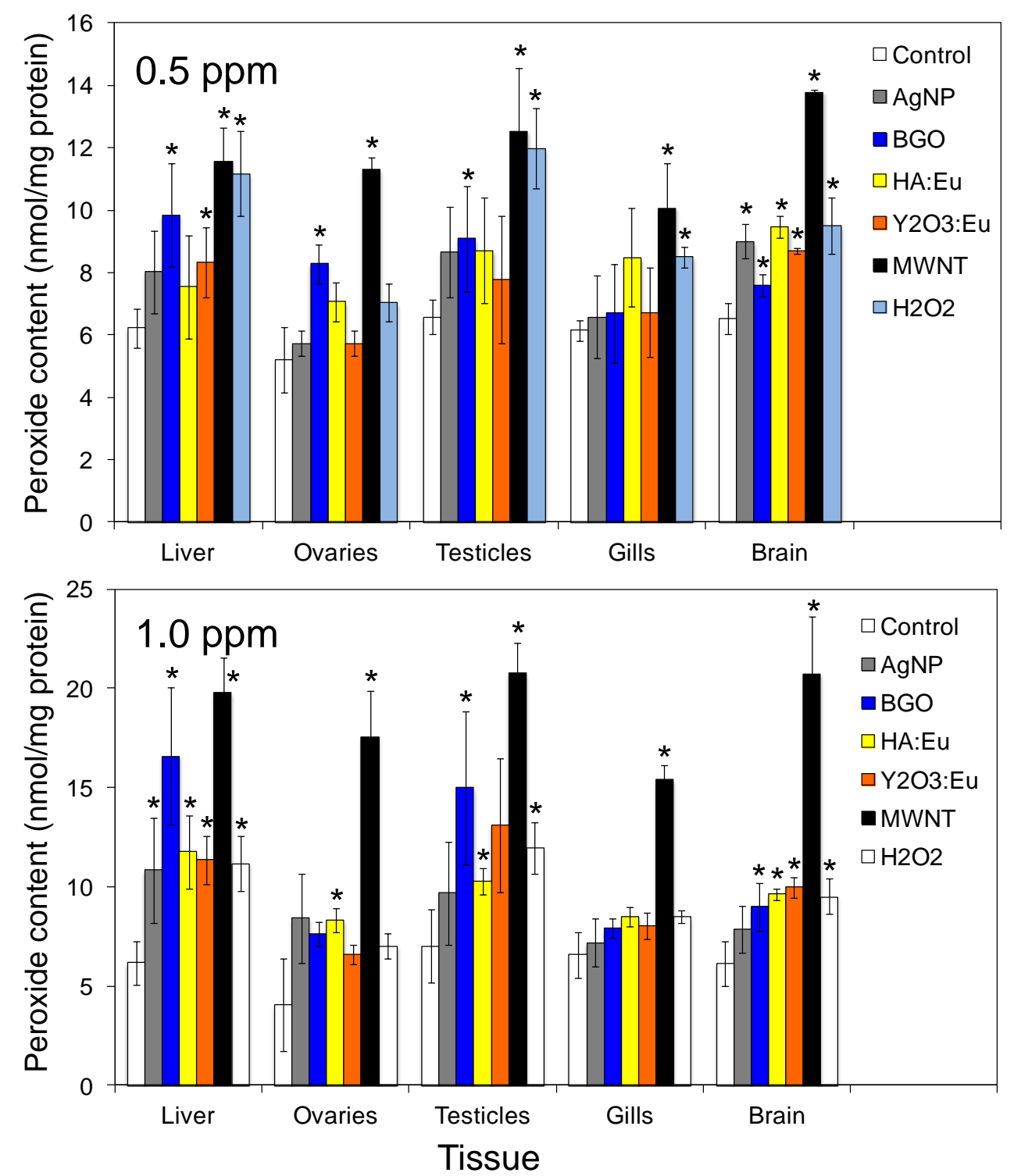

Figure 2. Lipid proxidation of different zebrafish tissues estimated as peroxyl content in lipids.

a) Fish exposed to 0.5 ppm of nanoparticles for $48 \mathrm{hrs}$. b) Fish exposed to $1 \mathrm{ppm}$ of nanoparticles for 48 hrs. (*)Values significantly different at $P<0.05$ with respect to the control.

The genetic expression of oxidative stress markers was measured in treated and untreated fish with $1 \mathrm{ppm}$ of NPs for $48 \mathrm{~h}$ (Table 3). Expression of superoxide dismutase (Sod1), the transcription factor Forkhead box protein O1 (FoxO1), and the glutamate-1-cysteine ligase catalytic subunit (Gclc) was quantified. $\beta$-actin (bact), tubulin alpha I (Tub) and TATA-box binding protein (Tbp) transcripts were used to standardize the results by eliminating variations in mRNA and cDNA quantity. No significant differences were found in the gene expression of any marker gene in liver, brain nor whole fish body (Table 3). These results may indicate that $48 \mathrm{~h}$ is not enough time for fish to metabolically compensate the accumulation of ROS caused by NPs 
exposure by modifying the expression of these genes involved in contending with oxidative stress.

Table 3. Relative mRNA levels of oxidative stress related genes in zebrafish exposed to nanoparticles (mean \pm standard deviation). Values are relative to control fish.

AgNP
\begin{tabular}{|l|c|c|c|}
\hline Gene & Brain & Liver & Whole body \\
\hline FoxO1a & $0.97( \pm 0.41)$ & $0.86( \pm 0.13)$ & $1.04( \pm 0.45)$ \\
\hline Gclc & $0.78( \pm 0.07)$ & $1.05( \pm 0.09)$ & $1.38( \pm 0.31)$ \\
\hline Sod1 & $0.68( \pm 0.17)$ & $0.62( \pm 0.07)$ & $0.94( \pm 0.19)$ \\
\hline
\end{tabular}

BGO

\begin{tabular}{|l|c|c|c|}
\hline Gene & Brain & Liver & Whole body \\
\hline FoxO1a & $1.18( \pm 0.08)$ & $0.64( \pm 0.43)$ & $0.68( \pm 0.28)$ \\
\hline Gclc & $0.83( \pm 0.06)$ & $1.08( \pm 0.67)$ & $1.24( \pm 0.06)$ \\
\hline Sod1 & $0.72( \pm 0.10)$ & $1.65( \pm 0.63)$ & $1.04( \pm 0.26)$ \\
\hline
\end{tabular}

\section{MWNT-COOH}

\begin{tabular}{|l|c|c|c|}
\hline Gene & Brain & Liver & Whole body \\
\hline FoxO1a & $0.95( \pm 0.03)$ & $1.28( \pm 0.21)$ & $1.29( \pm 0.41)$ \\
\hline Gclc & $0.63( \pm 0.16)$ & $1.02( \pm 0.13)$ & $1.04( \pm 0.23)$ \\
\hline Sod1 & $0.95( \pm 0.27)$ & $1.44( \pm 0.29)$ & $1.38( \pm 0.28)$ \\
\hline
\end{tabular}

$\mathbf{Y}_{2} \mathbf{O}_{3}-\mathbf{E u}^{3+}$
\begin{tabular}{|l|c|c|c|}
\hline Gene & Brain & Liver & Whole body \\
\hline FoxO1a & $0.73( \pm 0.06)$ & $0.70( \pm 0.18)$ & $0.71( \pm 0.13)$ \\
\hline Gclc & $0.94( \pm 0.08)$ & $0.74( \pm 0.14)$ & $0.88( \pm 0.07)$ \\
\hline Sod1 & $0.73( \pm 0.14)$ & $1.02( \pm 0.62)$ & $0.82( \pm 0.07)$ \\
\hline
\end{tabular}

\section{Discussion}

Our results demonstrated that NPs, after $48 \mathrm{~h}$ exposure and independently of its chemical nature, induce protein oxidation and lipid peroxidation of different zebrafish tissues (Figs. 1 and 2). Lipid peroxidation is also one of the earliest indicators of oxidative stress (Hwang and Kim, 2007). Reactive oxygen species (ROS) are able to oxidize unsaturated fatty acids producing lipid peroxides. Lipid peroxidation may play an important role in carcinogenesis (Cai et al., 2012), in the molecular mechanisms of multiple sclerosis (Ferreti and Bacchetti, 2011), in Parkinson's disease (Jenner, 1991), and there is increasing evidence of its role in diabetes (Piconi et al., 2003), among other diseases. In comparison with other nanoparticles, HA:Eu showed the lower oxidative stress levels in the different tissues. However, HA:Eu nanoparticles, depending on the shape and concentration, could induce hatching inhibition in fish and a reduction of metabolic activity of the cells (Zhao et al., 2013). Hydroxyapatite NPs could be aggregated into bigger particles around the membrane protein, inducing low toxicity to development of zebrafish embryos, when compared to $\mathrm{SiO}_{2}$ and $\mathrm{TiO}_{2}$ nanoparticles $(\mathrm{Xu}$ et al., 2012). Apoptosis could be the possible mechanism of hydroxyapatite NPs toxicity, as reported from in vitro cell experiments (Wang et al., 2012).

BGO and AgNP induced moderate protein oxidation and lipid peroxidation. AgNPs have potent antibacterial activity making them interesting for several biomedical applications and they are extensively used in the healthcare, food industries, many domestic applications and as additive in surface materials and textiles. Although there is 
abundant literature on their toxic effects, there is little understanding of the AgNPs interactions with microorganisms (Maillard and Hartemann, 2012). Oxidative stress induced by AgNP has been reported from in vitro cell experiments (Arora et al., 2008; Carlson et al, 2008; AshaRani et al., 2009; Piao et al., 2011) and in vivo experiments including fish (Choi et al., 2010; Gagné et al., 2012; Wu and Zhou, 2012), but the toxicity mechanism is still not fully elucidated. In these studies at AgNP concentrations of 1 to $100 \mathrm{ppm}$, the hepatic lipid peroxidation, measured as the malondialdehyde generation, increased from 1.5 to 2 -fold, results that are in agreement with those obtained in this work.

Bismuth germanate (BGO) has been used as a scintillator in detectors, industry and medicine for the past forty years (Weber and Monchamp, 1973; Chung and Chan, 1994; Macedo et al., 2004). On the contrary to the controversial AgNP, there is not information on BGO toxicity. As far as we know, this is the first report on the oxidative effects of BGO nanoparticles. BGO nanoparticles showed high protein oxidation at 1 ppm in liver, ovaries and brain, while lipid peroxidation was found only in liver and testicles (Figs. 1 and 2).

Yttrium oxide nanoparticles activated with europium $\left(\mathrm{Y}_{2} \mathrm{O}_{3}: \mathrm{Eu}\right)$ showed high oxidative stress, especially in proteins (Figs. 1 and 2). $\mathrm{Y}_{2} \mathrm{O}_{3}: \mathrm{Eu}$ is the most red-emitting phosphor widely used in color TV displays and fluorescent lamps. A few studies of the effect of $\mathrm{Y}_{2} \mathrm{O}_{3}$ nanoparticles are available in literature. Human aortic endothelial cells exposed to $\mathrm{Y}_{2} \mathrm{O}_{3}$ nanoparticles showed that the NPs were often present within cytoplasmic vesicles, where a transformation is suspected, and their density increased with nanoparticle concentration (Gojova et al., 2007). In addition, $\mathrm{Y}_{2} \mathrm{O}_{3}$ nanoparticles induced the up-regulation of inflammatory markers observed at the translational level. This effect was concentration dependent, with a statistically significant increase from concentrations of $10 \mathrm{ppm}$ to $50 \mathrm{ppm}$. As mentioned before, the suggested pathway for nanoparticle-induced inflammation in human aortic endothelial cells is the production of reactive oxygen species (ROS). However, Schubert et al. (2006) suggest that $\mathrm{Y}_{2} \mathrm{O}_{3}$ nanoparticles could act as antioxidants in neurons.

The carboxylated multi-walled carbon nanotubes (MWCNT-COOH) showed the highest induction of both protein oxidation and lipid peroxidation at the two tested concentrations. The toxicity of MWCNT and their functionalized derivatives has been extensively reviewed (Lam et al., 2006; Schubert et al., 2006; Lacerda et al., 2006; Sargent et al., 2010; Shvedova et al., 2012). Carbon nanotubes (CNT) represent an special case, because relatively high content of transition metals, particularly $\mathrm{Fe}, \mathrm{Cu}$, $\mathrm{Cr}$, and $\mathrm{Ni}$ (Tessonnier and $\mathrm{Su}, 2011$; Valko et al., 2005), are present in some preparations. It is well known that the presence of these metals in single-walled carbon nanotubes (SWCNT) may be important in determining redox-dependent responses of macrophages (Kagan et al., 2006; Pulskamp et al., 2007). Non-purified iron-rich SWCNT induced higher concentrations of intracellular ROS, specifically hydroxyl radicals, determined by EPR spin-trapping analysis, and decreasing the mitochondrial membrane potential, than purified SWCNT. Two main consequences of ROS production induced by the presence of carbon nanotubes have been proposed: Inflammation, since ROS production is thought to be an essential requirement for inflammasome activation, and the activation of the NADPH oxidase. The recognition of MWCNT-COOH by phagocytes could lead to their internalization via endocytosis with subsequent fusion with lysosomes within the cell. Then, the lysosomes disruption may lead to the activation of the inflammasome. However, the contribution of each 
ROS generation mechanism (mitochondria-generated and NADPH oxidase-generated ROS) to the activation of the inflammasome induced by carbon nanotubes requires further investigation (Valko et al., 2005).

A state of oxidative stress is created when the generation of ROS is higher than the rate of their elimination. Jones (2006) redefined oxidative stress as "a disruption of redox signaling and control" bringing antioxidant enzymes into the picture and making the point that the deleterious effect is observed when the accumulation of ROS surpasses the cell's defense capacity. In addition to non-enzymatic defenses mediated by some molecules, enzymatic detoxification of ROS constitutes a major component of oxidative stress defense systems and involves enzymes such as superoxide dismutases, catalases and peroxidases. Basal levels of these enzymes work in concert to remove endogenously produced ROS and keep their levels within physiologically safe limits. In our experiments, the expression of superoxide dismutase (Sod1), the transcription factor Forkhead box protein O1 (FoxO1), and the glutamate-l-cysteine ligase catalytic subunit (Gclc) were quantified in different fish tissues. No significant differences were found in the gene expression of any marker gene in liver, brain and fish body (Table 3). These results suggest that after only two days of NPs exposure, the fish is not able to metabolically compensate, by the expression of these genes, the oxidative stress caused by the presence of nanoparticles, leading to protein oxidation and lipid peroxidation in the different fish tissues. The exposure of cultured human cells to concentrations 40times higher than those used in this work of cerium oxide and titanium dioxide NPs of different sizes, induced the expression of oxidative stress-related genes such as heme oxygenase-1, catalase, glutathione S-transferase, and thioredoxin reductase (Park et al., 2008). After prolonged exposures to relatively high concentrations, low cytotoxicity has been seen in cultured cells owing to increases in oxidative stress, most likely due to the increase of antioxidant defenses (Thakor et al., 2011). Recently, Gagné et al. (2012) performed a DNA microarray study of rainbow trout (Oncorhynchus mykiss) in order to identify the fundamental mode of action of AgNPs using the gene expression level. They found that $31 \%$ of the genes (from 270 studied genes) responded to either nano- or dissolved-silver, while $9.6 \%$ were specifically affected by AgNPs. The authors conclude that the increased lipid peroxidation and the reduced level of DNA strand breaks induced by AgNPs could not be explained by the presence of dissolved silver.

It seems that ROS generation by NPs is generated through several mechanisms including redox-cycling pathways, inflammation and protein denaturation. In addition, the activation of lysosomes may trigger a mitochondrial apoptosis, with the subsequent ROS production. Recently it has been demonstrated that the presence of antioxidant (vitamin E) protects cultured cells from the injury induced by SWCNT through the down-regulation of oxidative stress and prevention of mitochondria mediated apoptosis (Wang et al., 2012).

Thus, the oxidative stress is not the sole origin of the toxic effects of NPs. A better understanding of the nature and significance of such oxidative signaling and metabolic responses will offer new opportunities to control the effects of nanoparticles, including their toxicity. The cell could be considered as a collection of "nanomachines" (van den Heuvel and Dekker, 2007) to which engineered nanomaterials may interfere directly with cellular functions. A priority challenge of nanotechnology is to understand the mechanism leading to oxidative stress and its metabolic consequences in order to emphasize in a better nanomaterials design to prevent toxic effects that would put in risk animal health and environmental equilibrium. 
Acknowledgements. This work has been funded by the National Council of Science and Technology of Mexico (CONACyT). We thank Dr. Lucia Perezgasga and Rosa Roman for their technical assistance.

\section{REFERENCES}

[1] Adibhatla, R.M., Hatcher, J.F. (2010): Lipid oxidation and peroxidation in CNS health and disease, from molecular mechanisms to therapeutic opportunities. - Antioxidants and Redox Signaling 12:125-169.

[2] Arora, S., Jain, J., Rajwade, J.M., Paknikar, K.M. (2008): Cellular responses induced by silver nanoparticles, in vitro studies. - Toxicological Letters 179: 93-100.

[3] Asha Rani, P.V., Low Kah Mun, G., Hande, M.P., Valiyaveettil, S. (2009): Cytotoxicity and genotoxicity of silver nanoparticles in human cells. - ACS Nano 3: 279-290.

[4] Baalousha, M., Lead, J.R., von der Kammer, F., Hofmann, T. (2009): Natural colloids and nanoparticles in aquatic and terrestrial environments. - In: Lead, J.R. \& Smith, E. (eds) Environmental and human health impacts of nanotechnology. pp 109-161. John Wiley \& Sons, Chichester, United Kingdom.

[5] Baun, A., Hartmann, N.B., Grieger, K., Kusk, K.O. (2008): Ecotoxicity of engineered nanoparticles to aquatic invertebrates, a brief review and recommendations for future toxicity testing. - Ecotoxicology 17: 387-395.

[6] Cai, F., Dupertuis, Y.M., Pichard, C. (2012): Role of polyunsaturated fatty acids and lipid peroxidation on colorectal cancer risk and treatments. - Current Opinion in Clinical and Nutrition Metabolic Care 15:99-106.

[7] Carlson, C., Hussain, S.M., Schrand, A.M., Braydich-Stolle, L.K., Hess, K.L., Jones, R.L., Schlager, J.J. (2008): Unique cellular interaction of silver nanoparticles, sizedependent generation of reactive oxygen species. - Journal of Physical Chemistry B 112: 13608-13619.

[8] Choi, J.E., Kim, S., Ahn, J.H., Youn, P., Kang, J.S., Park, K., Yi, J., Ryu, D.Y. (2010): Induction of oxidative stress and apoptosis by silver nanoparticles in the liver of adult zebrafish. - Aquatic Toxicology 100: 151-159.

[9] Christian, P., Von der Kammer, F., Baalousha, M., Hofmann, T. (2008): Nanoparticles, structure, properties, preparation and behaviour in environmental media. - Ecotoxicology 17: 326-343.

[10] Chung, C., Chan, C.C. (1994): Application of BGO detector to monitor in situ ${ }^{16} \mathrm{~N}$ concentration in a reactor pool. - Journal of Radioanalytical and Nuclear Chemistry 180: 131-371.

[11] Delay, M., Frimmel, F.H. (2012): Nanoparticles in aquatic systems. - Analytical and Bioanalytical Chemistry 402:583-592.

[12] Ferretti, G., Bacchetti, T. (2011): Peroxidation of lipoproteins in multiple sclerosis. Journal of Neurological Sciences 311: 92-97.

[13] Gagné, F., André, C., Skirrow, R., Gélinas, M., Auclair, J., van Aggelen, G., Turcotte, P., Gagnon, C. (2012): Toxicity of silver nanoparticles to rainbow trout: A toxicogenomic approach. - Chemosphere 89: 615-622.

[14] Gay, G.A., Gebicki, J.M. (2003): Measurement of protein and lipid hydroperoxides in biological systems by the ferric-xylenol orange method. - Analytical Biochemistry 315: 29-35.

[15] Gojova, A., Guo, B., Kota, R.S., Rutledge, J.C., Kennedy, I.M., Barakat, A.I. (2007): Induction of inflammation in vascular endothelial cells by metal oxide nanoparticles: Effect of particle composition. - Environmental Health Perspectives 115: 403-409.

[16] Han, X., Corson, N., Wade-Mercer, P., Gelein, R., Jiang, J., Sahu, M., Biswas, P., Finkelstein, J.N., Elder, A., Oberdörster, G. (2012): Assessing the relevance of in vitro studies in nanotoxicology by examining correlations between in vitro and in vivo data. Toxicology 297: 1-9. 
[17] Hwang, E.S., Kim, G.H. (2007): Biomarkers for oxidative stress status of DNA, lipids, and proteins in vitro and in vivo cancer research. - Toxicology 229: 1-10.

[18] Jenner, P. (1991): Oxidative stress as a cause of Parkinson's disease. - Acta Neurologica Scandinavica Suppl. 136: 6-15.

[19] Jones, D.P. (2006): Redefining oxidative stress. - Antioxidant and Redox Signaling 8: 1865-1879.

[20] Kagan, V.E., Tyurina, Y.Y., Tyurin, V.A., Konduru, N.V., Potapovich, A.I., Osipov, A.N., Kisin, E.R., Schwegler-Berry, D., Mercer, R., Castranova, V., Shvedova, A. (2006): Direct and indirect effects of single walled carbon nanotubes on RAW 264.7 macrophages: Role of iron. - Toxicological Letters 165: 88-100.

[21] Kamat, J.P., Devasagayam, T.P., Priyadarsini, K.I., Mohan, H. (2000): Reactive oxygen species mediated membrane damage induced by fullerene derivatives and its possible biological implications. - Toxicology 155: 55-61.

[22] Lacerda, L., Bianco, A., Prato, M., Kostarelos, K. (2006): Carbon nanotubes as nanomedicines, from toxicology to pharmacology. - Advanced Drug Delivery Reviews 58: $1460-1470$.

[23] Lam, C.W., James, J.T., McCluskey, R., Arepalli, S., Hunter, R.L. (2006): A review of carbon nanotube toxicity and assessment of potential occupational and environmental health risks. - Critical Reviews in Toxicology 36: 189-217.

[24] Lead, J.R., Wilkinson, K.J. (2006): Aquatic colloids and nanoparticles: Current knowledge and future trends. - Environmental Chemistry 3: 159-171.

[25] Levine, R.L., Williams, J.A., Stadtman, E.R., Shacter, E. (1991): Carbonyl assays for determination of oxidatively modified proteins. - Methods in Enzymology 233: 346-357.

[26] Limbach, L.K., Wick, P., Manser, P., Grass, R.N., Bruinink, A., Stark, W.J. (2007): Exposure of engineered nanoparticles to human lung epithelial cells: Influence of chemical composition and catalytic activity on oxidative stress. - Environmental Sciences and Technology 41: 4158-4163.

[27] Lin, Y., Rao, A.M., Sadanadan, B., Kenik, E.A., Sun, Y.P. (2002): Functionalizing multiple-walled carbon nanotubes with aminopolymers. - Journal of Physical Chemistry B 106: 1294-1298.

[28] Lowry, G.V., Espinasse, B.P., Badireddy, A.R., Richardson, C.J., Reinsch, B.C., Bryant, L.D., Bone, A.J., Deonarine, A., Chae, S., Therezien, M., Colman, B.P., Hsu-Kim, H., Bernhardt, E.S., Matson, C.W., Wiesner, M.R. (2012): Long-term transformation and fate of manufactured $\mathrm{Ag}$ nanoparticles in a simulated large scale freshwater emergent wetland. - Environmental Sciences and Technology 46: 7027-7036.

[29] Nowack, B., Bucheli, T.D. (2007): Occurrence, behavior and effects of nanoparticles in the environment. - Environmental Pollution 150: 5-22.

[30] Macedo, Z.S., Silva, R.S., Valerio, M.E.G., Hernandes, A.C.. (2004): Radiation detectors based on laser sintered $\mathrm{Bi}_{4} \mathrm{Ge}_{3} \mathrm{O}_{12}$ ceramics. Nuclear Instuments and Methods B 218: 153157.

[31] McIntyre, R. (2012): Common nano-materials and their use in real world applications. Science Progress 95: 1-22.

[32] Millard, J.Y., Hartemann, P. (2012): Silver as an antimicrobial: Facts and gaps in knowledge. - Critical Reviews in Microbiology 39: 373-383.

[33] Moller, P., Jacobsen, N.R., Folkmann, J.K., Danielsen, P.H., Mikkelsen, L., Hemmingsen, J.G., Vesterdal, L.K., Forchhammer, L., Wallin, H., Loft, S. (2010): Role of oxidative damage in toxicity of particulates. - Free Radical Research 44: 1-46.

[34] Mougiakakos. D,, Okita, R., Ando, T., Dürr, C., Gadiot, J., Ichikawa, J., Zeiser, R., Blank, C.C., Johansson, C., Kiessling, R. (2012): High expression of GCLC is associated with malignant melanoma of low oxidative phenotype and predicts a better prognosis. Journal of Molecular Medicine 90: 935-944.

[35] Nel, A., Xia, T., Madler, L., Li, N. (2006): Toxic potential of materials at the nanolevel. Science 311: 622-627. 
[36] Nourooz Zadeh, J., Tajaddini Sarmadi, J., Wolff, S.P. (1994): Measurement of plasma hydroperoxide concentrations by the ferrorus oxidation-xylenol orange assay in conjunction with triphenylphosphine. - Analytical Biochemistry 220: 403-409.

[37] Oberdörster, E. (2004): Manufactured nanomaterials (fullerenes, C60) induce oxidative stress in the brain of juvenile largemouth bass. - Environmental Health Perspectives 112: 1058-1062.

[38] Oviedo, M.J., Contreras, O., Vazquez-Duhalt, R., Carbajal-Arizaga, G.G., Hirata, G.A., McKittrick, J. (2012): Photoluminescence of europium-activated hydroxyapatite nanoparticles in body fluids. - Science of Advanced Materials 4:58-562.

[39] Papp, T., Schiffmann, D., Weiss, D., Castranova, V., Vallyathan, V., Rahman, Q. (2008): Human health implications of nanomaterial exposure. - Nanotoxicology 2: 9-27.

[40] Pattan, G., Kaul, G. (2014): Health hazards associated with nanomaterials. - Toxicology and Industrial Health 30: 499-519.

[41] Park, E-J., Choi, J., Park, Y-K., Park, K. (2008): Oxidative stress induced by cerium oxide nanoparticles in cultured BEAS-2B cells. - Toxicology 245: 90-100.

[42] Piao, M.J., Kang, K.A., Lee, I.K., Kim, H.S, Kim, S., Choi, J.Y., Choi, J., Hyun, J.W. (2011): Silver nanoparticles induce oxidative cell damage in human liver cells through inhibition of reduced glutathione and induction of mitochondria-involved apoptosis. Toxicological Letters 201: 92-100.

[43] Piconi, L., Quagliaro, L., Ceriello, A. (2003): Oxidative stress in diabetes. - Clinical Chemistry and Laboratory Medicine 41: 1144-1149.

[44] Powell, M.C., Kanarek, M.S. (2006): Nanomaterial health effects. Part 1: Background and current knowledge. - Wisconsin Medical Journal 105: 16-20.

[45] Pulskamp, K., Diabaté, S., Krug, H.F. (2007): Carbon nanotubes show no sign of acute toxicity but induce intracellular reactive oxygen species in dependence on contaminants. Toxicology Letters 168: 58-74.

[46] Ray, P.C., Yu, H., Fu, P.P. (2009): Toxicity and environmental risks of nanomaterials: Challenges and future needs. - Journal of Environmental Science and Health Part C 27: 1-35.

[47] Sargent, L.M., Reynolds, S.H., Castranova, V. (2010): Potential pulmonary effects of engineered carbon nanotubes: In vitro genotoxic effects. - Nanotoxicology 4: 396-408.

[48] Schubert, D., Dargusch, R., Raitano, J., Chan, S.W. (2006): Cerium and yttrium oxide nanoparticles are neuroprotective. - Biochemical and Biophysical Research Communications 342: 86-91.

[49] Sharifi, S., Behzadi, S., Laurent, S., Laird Forrest, L., Stroevee, P., Mahmoudi, M. (2012): Toxicity of nanomaterials. - Chemical Society Reviews 41: 2323-2343.

[50] Shvedova, A.A., Pietroiusti, A., Fadeel, B., Kagan, V.E. (2012): Mechanisms of carbon nanotube-induced toxicity: Focus on oxidative stress. - Toxicolology and Applied Pharmacology 261: 121-133.

[51] Stadtman, E.R. (2004): Role of oxidant species in aging. - Current Medicinal Chemistry 11: $1105-1112$.

[52] Stadtman, E.R., Oliver, C.N. (1991): Metal-catalyzed oxidation of proteins. - Journal of Biological Chemistry 266: 2005-2008.

[53] Stark, W.J. (2011): Nanoparticles in biological systems. - Angewandte Chemie International Edition 50: 1242-1258.

[54] Stone, V., Clift, M.J.D., Johnston, H. (2009): Human Toxicology and Effects of Nanoparticles. In : Lead, J.R. \& Smith, E. (eds) Environmental and human health impacts of nanotechnology pp. 357-388. John Wiley \& Sons, Chichester, U.K.

[55] Subauste, A.R., Burant, C.F. (2007): Role of FoxO1 in FFA-induced oxidative stress in adipocytes. - American Journal of Physiology: Endocrinology and Metabolism 293: E159-64. 
[56] Taxak, V.B., Khatkar, S.P., Han, S.D., Kumar, R., Kumar, M. (2009): Tartaric acidassisted sol-gel synthesis of $\mathrm{Y}_{2} \mathrm{O}_{3}, \mathrm{Eu}^{3+}$ nanoparticles. - Journal of Alloys and Compounds 469: 224-228.

[57] Tessonnier, J.P., Su, D.S. (2011): Recent progress on the growth mechanism of carbon nanotubes: A review. - ChemSusChem 4: 824-847.

[58] Thakor, A.S., Paulmurugan R, Kempen P, Zavaleta C, Sinclair R, Massoud TF, Gambhir SS. (2011): Oxidative stress mediates the effects of Raman-active gold nanoparticles in human cells. - Small 7: 126-136.

[59] Unfried, K., Albrecht C, Klotz LO, Von Mikecz A, Grether-Beck S, Schins RPF. (2007): Cellular responses to nanoparticles: Target structures and mechanisms. - Nanotoxicology 1: 52-71.

[60] Valko, M., Morris, H., Cronin, M.T. (2005): Metals, toxicity and oxidative stress. Current Medical Chemistry 12: 1161-1208.

[61] van den Heuvel, M.G., Dekker, C. (2007): Motor proteins at work for nanotechnology. Science 317: 333-336.

[62] Wang, J., Chena, C., Liu, Y., Jiao, F., Li, W., Lao, F., Li, Y., Li, B., Ge, C., Zhou, G., Gao, Y., Zhao, Y., Chai, Z. (2008): Potential neurological lesion after nasal instillation of $\mathrm{TiO}(2)$ nanoparticles in the anatase and rutile crystal phases. - Toxicology Letters 183: 72-80.

[63] Wang, L., Zhou, G., Liu, H., Niu, X., Han, J., Zheng, L., Fan, Y. (2012): Nanohydroxyapatite particles induce apoptosis on MC3T3-E1 cells and tissue cells in SD rats. - Nanoscale 4: 2894-2899.

[64] Weber, M.J., Monchamp, R.R. (1973): Luminescence of $\mathrm{Bi}_{4} \mathrm{Ge}_{3} \mathrm{O}_{12}$ : Spectral and decay properties. - Journal of Applied Physics 44: 5495-5499.

[65] Wiesner, M.R. (2006): Responsible development of nanotechnologies for water and wastewater treatment. - Water Science and Technolology 53: 45-51.

[66] Wiesner, M.R., Bottero, J-Y. (2007): Environmental nanotechnology - applications and impacts of nanomaterials. McGraw-Hill, New York.

[67] Wiesner, M.R., Bottero, J-Y. (2011): A risk forecasting process for nanostructured materials, and nanomanufacturing. - Comptes Rendues Physique 12: 659-668.

[68] Wigginton, N.S., Haus, K.L., Hochella, M.F. Jr. (2007): Aquatic environmental nanoparticles. - Journal of Environmental Monitoring 9: 1306-1316.

[69] Wu, Y., Zhou, Q. (2012): Dose- and time-related changes in aerobic metabolism, chorionic disruption, and oxidative stress in embryonic medaka (Oryzias latipes): Underlying mechanisms for silver nanoparticle developmental toxicity. - Aquatic Toxicology 124-125: 238-246.

[70] Xu, Z., Zhang, Y.L., Song, C., Wu, L.L., Gao, H.W. (2012): Interactions of hydroxyapatite with proteins and its toxicological effect to zebrafish embryos development. - PLoS One 7: e32818.

[71] Zhao, X., Ong, K.J., Ede, J.D., Stafford, J.L., Ng, K.W., Goss, G.G., Loo, S.C. (2012): Evaluating the toxicity of hydroxyapatite nanoparticles in catfish cells and zebrafish embryos. - Small 9: 1734-1741. 